\title{
Traces of History in Tere Liye's Novels Towards the Development of Teaching Material for Historical Texts Teaching in High School
}

\author{
Ayu Nurmalayani* \\ Magister in Indonesian Language \\ Education and Literature \\ Universitas Mataram \\ Mataram, Indonesia \\ ayurengganisa1la@gmail.com
}

\author{
Burhanuddin Burhanuddin \\ Magister in Indonesian Language \\ Education and Literature \\ Universitas Mataram \\ Mataram, Indonesia \\ burhanuddin@unram.ac.id
}

\author{
Johan Mahyudi \\ Magister in Indonesian Language \\ Education and Literature \\ Universitas Mataram \\ Mataram, Indonesia \\ johanmahyudi@unram.ac.id
}

\begin{abstract}
This study aimed at describing the historical traces in Tere Liye's novels. The research method used is descriptive qualitative in the form of historical traces in the novel by Tere Liye. The data of this research are in the form of discourse in four Tere Liye novels. The primary source of the data is the novel written by Tere Liye that are Rindu, Tentang Kamu, Ross dan Sunset, Anak Cahaya. The secondary sources of the data are theses, articles, and the internet. The data were collected through literature, attentive and note-taking techniques. The data were analyzed using structural genetic analysis of literature through a historical extrinsic point of view. The results of the research are historical traces found in four Tere Liye novels, Indonesian Communist Party (PKI) history in the novel Tentang Kamu and The Children of Light. In these two novels, the history of the Indonesian Communist Party $\{\mathrm{PKI}\}$ is proven by the historical fact that the PKI betrayal did occur in Indonesia in 1948 and 1965. Likewise, in the novel Rose dan Sunset, there are historical traces about the Bali bombings. Historical facts prove that there was a big explosion in 2002 in the Kuta area of Bali. The pilgrimage journey in the Dutch colonial era, contained in the novel Rindu. The takeover of the pilgrimage from kiyai by the Dutch by providing a steamboat that occurred in the 1900s became a historical fact that supported it. The results of this analysis can be developed as teaching materials, especially for historical story text material in high school.
\end{abstract}

Keywords - historical traces, historical facts, teaching materials

\section{INTRODUCTION}

Literary work is the result of the creation and reflection of writers about everything that is reflected in the form of art and culture. Literary works develop along with the development of civilization which is passed by humans as the most important element of its formation. One of the works which is the result of a literary creation and contemplation is a novel. According to Ma'ruf in Imani, the novel is a literary genre other than short stories, poetry, and drama [1]. Literary work is a description of the results of a person's invention of life that begins with the attitudes, backgrounds, and beliefs of the author. Literary work was born in the midst of society as a result of the imagination of the author and his reflection on the social phenomena that surround him [2]. Meanwhile, according to Nurgiyantoro, novels are realistic works, which refer to higher realities and deeper psychology [3]. In this context, the novel is the work of the author's imagination that is realistic, something that exists in human life and contains noble values that can be applied in the lives of readers.

The reality that the author raises in his works cannot be separated from the environment and his past. This reality is mixed in stories that can inspire readers about something. For example, historical stories that are often raised in a literary work including novels. Rokhman, et al stated that literary works cannot be separated from the collectivity and historical context that contributed to it [4]. One of them is the stories contain in the novels written by Tere Liye. In his novels, Tere Liye takes much of history as the background for his story's depiction. Tere Liye composes a series of sentences that can represent a series of historical stories and reappear in the form of stories for literary readers to grasp the next era. This kind of writing is also intended to be able to offer various historical values to the reader. This is because historical values are values that can provide an understanding for the reader to be able to learn from historical events in addressing life.

There is no research related to historical traces in the novel written by Tere Liye, even though this can be used as a very interesting teaching material in the study of the historical text in high school. Previous research has only been related to (a) Firmansyah [5] the social dimension in the novel Negeri Para Bedebah; (b) Setiawan [6] the value of environmental love characters in the main character of Eliana's novel; (c) Sari, et al [7] social values in the novel Tentang Kamu; (d) Nuraini [8] about the structure of discourse in the novel Rindu; (e) Agustyaningrum, Hana, et al [9] about structural analysis and educational value of Pukat Novel characters [5]-[7]. Through this article, historical traces in the novel of Tere Liye will be discussed as well as the possibility of their development as teaching materials for teaching historical texts in high school.

Sugihastuti explained that history, in a narrow sense, studied the people of the past, as long as it could be examined from written statements that came from his day and then reach the present-day humans [8]. In a broad sense, history seeks to reveal the past man in living his history from the beginning, no matter whether the information he left was written or not ". It can be understood that history is a matter that reveals various events or life in the past which certainly has an impression or an image that is still remembered by humans today. In the Big Indonesian Dictionary, the word history has three 
meanings, namely: the origin; events, and incidents that actually happened in the past, history, knowledge, or description of events and incidents that actually happened in the past. Stories in history might be used by writers as Tere Liye did for his novels.

In some of Tere Liye's novels there is history that was once a dark story of the nation. This can be analyzed based on the traces left on some of his works. These traces can be proven by historical facts that have been documented so that it is easier to trace the truth. Historical traces that are collaborated with historical facts can be used/developed as teaching material.

Gatot states that development is the process of translating product specifications into physical forms [9]. Furthermore, it explaines that development is the act of providing something from not available to being available or making improvements from something that is available to be more appropriate and more efficient. In this case, the development of teaching materials is a systematic process in identifying, developing, and evaluating learning content and strategies aimed at achieving learning objectives more effectively and more efficiently. The development of teaching materials is a form of developing learning strategies that are following certain principles that are adapted from learning theories [10]. In addition, Syahid explained that the development of teaching materials is not only based on the interests of the developer, but also is an alternative problem-solving learning.

Gatot also added that "good teaching materials must be able to meet curriculum demands that contain specified competencies" [9]. The teaching materials are directed according to the demands of the curriculum. Competencies provided are following the curriculum. Teaching materials can also be viewed in terms of the attractiveness and use of language so that it can be used effectively [9]. Greene \& Petty in Haeruddin et al. state that the characteristics of quality teaching materials are (1) can attract attention, (2) arouse learning motivation, (3) contain interesting illustrations, (4) use clear language, (5) ) there is a connection with other lessons, and (6) avoiding vague concepts [11].

\section{METHOD}

The method used in this research is descriptive qualitative. Qualitative data are those related to quality [1]. According to Moleong, in descriptive analysis, rather than numbers, the data are in the form of words and images [12]. The research method used is descriptive qualitative research object in the form of historical traces in the novel written by Tere Liye. The data of this research are in the form of discourse in four novels of Tere Liye. The primary sources of the data are novels (Rindu, Tentang Kamu, Ross and Sunset, Anak Cahaya) written by Tere Liye. The secondary sources of the data were obtained from research findings or studies conducted by others contained in various libraries such as magazines, literary criticism books, papers, articles in literary journals, findings of literature seminar, and relevant previous research findings. The data were analyzed using structural genetic methods that examine literature through an historical extrinsic point of view. Jabrohim in Basid et al. explained that genetic structuralism is an approach in literary research that was born as a reaction to a purely antihistorical and causal structuralism approach [13].

\section{RESULT AND DISCUSSION}

History will not be separated from human life because every human being has a past, especially a nation. This past can be used as one of the important objects in someone's writing, including novelist. This is what Tere Liye did in his writings. Tere Liye is known as a very productive writer, it can be seen from his various works with varied events. One of the events that are often outlined in his stories is a historical event that occurred in Indonesia. Some of his novels deal with history as a setting for events. This can be proven by an analysis of some of the novels he produces. These historical traces can be proven by historical facts that have occurred in the past. The following is presented historical traces as well as the results of confirmation with existing historical facts.

\section{A. The History of the Indonesian Communist Party}

Define abbreviations and acronyms the first time they are used in the text, even after they have been defined in the abstract. Abbreviations such as IEEE, SI, MKS, CGS, sc, dc, and rms do not have to be defined. Do not use abbreviations in the title or heads unless they are unavoidable.

In the novel Tentang Kamu, the historical traces of the betrayal and rebellion of the Indonesian Communist Party can be found in the following fragments of the novel.

"like a pregnant woman, the political atmosphere in Indonesia is already very precarious. Disputes, friction, and even collisions began to occur in various regions. Provocation is an everyday view, hatred against religion continues to be echoed, as if all Kiai are hypocritical evil people. Anyone who speaks of religion is seen as holy-ass. Sri gradually understood the situation. that is, certain groups try to attack religion ... Upon arrival in the next village, dozens of people had gathered in the field. While singing, screaming, dancing. They wielded sharp weapons, brandishing machetes into the sky. Sri timidly crossed the field to Lastri's house. ... "I'm sorry, Sri." Mbak Lastri and Musoh appeared, "I would never have the heart to hurt you. You are my best friend, I like you since we first met. But I have to do this, you have to be tied up, you can't go anywhere for a while" [14].

"Our group has ruled over Jakarta, Sri." Musoh explained as he came out of the living room with a cloth wrapped around his head, carrying a sharp machete. The people partied on the deaths of the generals. A Revolutionary Council will be formed. It's time for the regional leaders to move. It's time we finish off the landlords, the Kiai, and the military. We will attack Madrasa of Kiai Ma'sum mala mini. Whoever is there will be killed. " ... "Don't do it, Musoh." Sri cried ... Musoh laughed, stepped outside, shouted to his followers. Dozens of people welcomed the call. Like crazy they danced with joy [14].

That day, in 1965. Envy has become an extraordinary hatred, which can even make the culprit heartless. Dozens of sharply armed masses led by Musoh have surrounded the Madrasa of Kiai Ma'sum. Just as the sun fell at the 
west foot, they rushed in. Wild faces, ferocious screams. Whatever is blocking, is finished. Students did not have time to fight back, they were preparing to establish Maghrib prayer when the masses came like a flood. ... At seven in the evening the madrasa complex was like a field of horror, blood flooded the mosque, the students' room, the road, to the madrasa field. The student's body is lying on its back. The mass of the Musoh group took Kiai Ma'sum and his family to the sugar factory to be executed [14].

Nine o'clock somewhere else. Musoh, Sulastri, and his masses celebrated at the sugar factory. They danced in front of the campfire that was burning high. The factory had been empty since they arrived, the factory staff stepping aside when they saw the crowd carrying sharp weapons. "Put them in the lodge." Sulastri exclaimed [14].

"Can your handsome husband who is fierce to take Musoh's position to save you now? Look, he is crawling like a pig." Arifin had sat down until one of them kicked him in the back. Forced him to crawl. The crowd laughed seeing it. "Long life of the poor people!" The enemy shouted, "Finish the landlords, hypocrites Kiai!" The crowd shouted back, brandishing sharp weapons into the air. "Tonight, you will know what it's like to be locked in a closed room, then the building is set on fire. I don't know which one will kill you first, go limp or burned by fire. Please enjoy. "Sulastri rebuked Kiai Ma'sum and his wife. Kiai Ma'sum's condition was heartbreaking, her eyes hurt, he could no longer see. His tongue has also been cut. Nyai Kiai is no less, her costs are full of blood. After all the members of the Kiai Ma'sum family were put into the warehouse, Sulastri stepped out, giving orders, "Close the door!" [14].

The historical facts that prove that fragments to be historical traces are described as follows [15].

The atmosphere in Magetan was tense, people in the pendhapa, except for the communist people, were herded into Magetan prison. The hands of Regent M. Ng. Sudibyo was turned back and bound by a bamboo rope so that he could not move. From Magetan prison the prisoners were transported by lorries to the Rejosari Gorang Gareng sugar factory. The regent and his entourage were also transported with their hands tied. Arrival of the Regent M.Ng. Sudibyo at the Rejosari sugar factory was witnessed by Sudirno, who was then only 14 years old.

The massacre at the Rejosari sugar factory premises was carried out on September 28, 1948 by communist executioners. At night, before being killed they were told to fast and after 9:00 to 11:00 those in loji rooms were bombarded with gunfire from outside through the cracks of the window. The entire room was flooded with fresh blood that pooled almost as high as an ankle. But good fortune was in favor of $\mathrm{KH}$. Rochib and one of his friends who inhabited one of the rooms in the lodge. Both of them survived the killing because every time there was a shot, $\mathrm{KH}$. Rochib took shelter on the sidewall. Before being arrested and taken to Rejosari, KH. Rochib is a religious teacher at Bangsri. He and about 300 others were arrested in Bangsri and held in the Rejosari sugar factory. In the process, 5 or 6 people in his hand are joined together so that if one of them is going to urinate or defecate, they must jointly follow him.

In the fragments of the novel above, it is clearly taken from the events of the betrayal of the Indonesian Communist Party in Madiun by paying attention to the languages of the characters such as "long live the poor people". Besides the background of the slaughtering such as sugar cane field, sugar factory, and loji. The way the Kiai kidnapped and killed brutally. In fact, not only religious leaders are treated as such, government figures such as village elders, sub-district governments and even regents experiences the same thing. The boarding schools were threatened; students and their teachers were slaughtered. This can be proven by the following historical facts.

The events in the fragments of the novel above are proved by the existence of a monument in Madiun which contains the names of scholars who were victims of the Indonesian Communist Party such as KH Imam Shofwan. $\mathrm{He}$ is the caretaker of the Thoriqussu'ada Rejosari Islamic boarding school in Madiun. KH Shofwan was buried alive in the well after being tortured many times. In fact, when he was put in the well, the Kiyai had a call to prayer. Two sons of KH Imam Shofwan, namely Kiai Zubeir and Kiai Bawani, were also victims and buried alive together.

Besides K.H. Imam Shofwan, some of the names listed on the monument are the family of the Pesantren Sabilil Mutaqin (Sabilil Mustaqin Boarding School) Takeran. Hadi Addaba 'and Imam Faham were teachers who were victims of the Indonesian Communist Party. Imam Faham is the younger brother of Muhammad Suhud, the uncle of the former chairman of Legislative Assembly, M Kharis Suhud. In addition to the Kiai there were also military officers, regional officials, journalists, and politicians who also became victims. The caretaker of the Sabilil Mutaqin Islamic Boarding School (KH) KH Zakaria (83 years) said, after the Friday prayer on September 17, 1948 his boarding school was visited by several leaders of the Indonesian Communist Party. The head of the group was led by Communist activist Suhud. They came accompanied by armed guards who were identified as security chiefs at Takeran.

In addition to the Novel Tentang Kamu, the Tere Liye novel containing the history of the Communist is the novel entitled "Anak Cahaya" which was published in December 2018. Besides the events of the Communist rebellion, there are some past events but they are not included in national history. So that the most dominant historical traces occurred is the history of the Indonesian Communist Party. This can be explained in the following fragments of the novel.

You are friends with young people who understand that religion is only a form of human powerlessness. That God does not exist. Religion is opium, something that is made to mislead people. Initially you are only sprayed by a little "spark" of such a thing. Then, slowly but surely, you started to burn. Slow down the process. Starting from interest, believing little by little, and finally become an important part of the denial of religion [16]. Of course, when you return home during the fasting month, you are at a pole far different from your grandparents. Grandfather 
was a mosque imam, while you called the mosque only as a place for fools. Grandfather became a role model of the population, while you chose not to fast, not to do tarawih prayer, even when Eid Al-Fitr you did not go to the mosque. ... "What kind of chat do you want?" Grandfather tried as wisely as possible. "About bigger things. How to create an even prosperity for the nation. There are no landlords, no commoners. Everything is the same." [16]

"The inhabitants of this village, if the harvest is small, they say it is God's will. Yet it was clear that it was because of their laziness that the harvest was minimal. Then, what do they say when they catch fish and only get a little? Again, it's God's will. Even though it was clear because they were afraid to dive deep inside. " ... "A year wandering, your temperament has changed, son. No fast, no prayer. Also never visiting the mosque," said Grandfather. For this problem, who knows how many times he repeated it. "It's also no use, sir. Humans will advance with the power and mind of their own. There is no divine intervention in human destiny. God does not exist "[16].

You are not lying. He did go to the mosque. But what he does will never be imagined. Yahid, the son of the mosque's Imam, that afternoon valiantly entered the mosque, then knocked down the pulpit, tore apart the mats used as a prayer mat, knocked down the wooden cupboard where the book of Al-Qura'an was kept. You also shouted furiously, "You fools! You fools! You don't understand progress!" That was among them shouted by him [16].

... "When words are no longer able to realize the ideals of struggle, it's time for our two hands to do it. Religion is opium. Damaging human reason! " [16].

"In many ways, the understanding of the Dulikas association actually makes sense. He wants justice for all people. Equal, same taste. There must be no inequality in society - some are very rich, the bourgeoisie, and there are those who make, proletarian groups. The association which he joined wanted to drive a revolution, prosper all the people, establish communist ideas throughout the country. But they closed themselves to the facts, not only those who wanted to oppose the Dutch colonialism, nor were they the only ones who wanted to help the people at large. And even more fatal, they did it the wrong way [16].

In several fragments of the novel "Anak Cahaya" shows that in this novel Tere Liye also tried to build a story by including historical events in it. Traces of history are seen in the description of the story where the characters hate religion and the expression that people who believe in God are fools. Just like the Indonesian Communist Party incident in Java, hatred and vandalism of places of worship such as mosques continued. Even hatred is spread even though it is by the child to his father. Apart from that, the ideas expressed cannot be denied that they are the Indonesian Communist Party. In the last quote the author clearly stated this party by the author through the father figure.

\section{B. The History of Bali Bombing in 2005}

The Bali bombing that occurred in 2005 in Jimbaran cannot be separated from the slick spotlight of Tere Liye to be used as a story in his novel. Although this event was only in the form of pieces in the history of the Indonesian nation's journey, it was very influential in many aspects of national life. The world view of the Indonesian people is not good. Indonesia is labeled as one of the countries that gave birth to many terrorists. In addition, tourism in Bali at that time began to worry because many tourists were afraid and worried about their safety. These historical traces can be seen in the following fragments.

I rushed to fix my sitting position. It's 17:15 already. In Jimbaran that means 18:15. In a few minutes the sun will set there [17].

... "Hey uncle, the cellphone also dropped." Jasmine bent down to pick up her cellphone in the sand, holding it out again to the man. This time Jasmine was certain that the person would be really angry because the phone screen on her gene phone had also broken. Sakura is like that, haphazardly. When walking, her footsteps her eyes sight do not in sync, I once told her when tracking at the foot of Mount Rinjani, Sakura's feet are often caught in the roots of trees. The man glared. Taking the cellphone roughly from Jasmine's hand. He had already lost ten very precious seconds. Ten decisive seconds. ... "Uncle, Jasmine, give me one flower instead." Jasmine wiped her sweaty forehead, innocently stuck out a blue rose. Calculate the replacement of broken goods [17].

But God, the bad guys only needed a second to ruffle Rosie's entire happiness. Ruffled everything. 00.00.00. The bomb timer perfectly touches zero ... In a slow, painful motion, in a slow-motion that cuts into the heart, I must be a full witness of the whole incident. Before Rosie was moved to take the flower stalk, before Nathan scrambled proudly of Sakura and Jasmine's hair, a loud boom sounded. The camera on a tripod suddenly shakes. Chaotic images were visible. People were running around. Screaming. Dark. The 29-inch screen hanging on the wall of my study is dark. And a second later the writing appeared, connection error. I was stunned, gasping. Skip standing. What is wrong? WHAT IS WRONG? Damn, my feet are stuck in a chair, I'm stuck on a thick carpet. God, what happened there? [17].

I gasped. My knees are weak. Exactly three hours and thirty minutes after the bomb exploded, I finally arrived at the location. And when he arrived at the Jimbaran parking lot, in front of the lined cafe building, the location which was usually crowded with tourists passing by, now looks like a former battle arena. Silent. Pathetic. Like there was no one there, even though many people were walking around. Silent, despite the ringing of the car siren, it was heard with deafening ears [17]

Ambulance cars sped in and out carrying victims. Officers in white uniforms look cheeky with blood redness. Fire engines lined the mouth of the cafe parking lot, trying to extinguish the fire. Police cars across here and there. Yellow tape stretched. The clerk was busy driving away people who were about to approach. Brandishing a club to an audience one or two scrambling to photograph the scene [17].

... "More than one hundred deaths have been found. Dozens of severe injuries. Bali is once again in mourning. " The sound of the live broadcast was faint. I snorted at 
the reporter. Nonsense. They did put on a show of sympathy when broadcasting it, but they were actually happy with this great news. Scrambling to air it first. Scrambling to become reporters who cover [17].

As for historical facts that can prove that the bombings in Jimbaran in the novel 'Sunset \& Rosie' were taken from the 2005 bombings. The 2005 Bali bombing was a series of bombings that occurred in Bali on October 1, 2005. There were three bombings, one in Kuta and two in Jimbaran with at least 23 people killed and 196 others injured. This suicide bombing had a significant impact on tourism in Bali since 12 October 2002, a similar bomb attack killed 202 people. According to the Head of the Antiterror Desk Office of the Coordinating Minister for Political, Legal and Security Affairs, Inspector General (Ret.) Ansyaad Mbai, preliminary evidence indicates that this attack was carried out by at least three suicide bombers in a model similar to the 2002 bombing. and the body that was destroyed in excess was considered as an evidence of suicide bombings. But there is also the possibility of the backpacks being hidden inside the restaurant before being blown up. Australian Federal Police Commissioner Mick Keelty said that the type of bomb used appeared to be different from the previous explosion which saw most of the victims killed and injured as a result of "sharp debris" (shrapnel), and not chemical explosions. Medical officials showed x-rays that a foreign object was described as a "pellet" inside the victim's body and a victim reported that ball bearings entered his back [18].

\section{The History of Hajj in the Dutch Colonial Period (1938)}

The journey of Hajj during the Dutch colonial in the 30s still used steamships. In those years the steamship as the most sophisticated transportation tool at sea. This journey of Hajj was developed by Tere Liye in the novel "Rindu", as stated in the fragments below.

At exactly one o'clock in the afternoon, the Blitar Holland passenger ship began its journey. Anna and Elsa, the two little girls stood on the open deck with their parents and dozens of other passengers as the ship began to move away from the harbor. Passengers returned a wave of their hands towards the escort crowd at the jetty that had let them go. There were one hundred and ninety Hajj passengers from Makassar who boarded the ship that year. Twice more than the previous year. Consisting of one hundred and thirty male worshipers, the remaining female worshipers [19].

The first Maghrib prayer on the ship was followed by only one male and several female pilgrims. The ship wasn't even one-third full yet. There are still many prospective pilgrims waiting in Surabaya, Semarang, Batavia, Lampung, Bengkulu, Padang, until finally, the last passenger rides on the Veranda of Mecca, Banda Aceh [19]

Those years were the heyday of the steam engine. A century before, people still used sailboats to cross the ocean. When the steam engine was invented, shipbuilders competed to create ships with propellers driven by engines.
The concept is simple. The water is heated in a closed container producing steam, then the hot, high-pressure steam is flowed into the engine, turning the propeller. Coal has become a favorite source of energy for heating water firewood has been abandoned [19].

Historical facts that can be used as evidence that Tere Liye raised the history of the pilgrimage in 1911-1938 as a setting event in the novel Rindu is as follows.

Efforts to improve Hajj services continue to be carried out by the Dutch East Indies government. New provisions for the transportation of hajj pilgrims from the Dutch East Indies to Mecca were rearranged to improve the policy of the 1898 pilgrimage Ordinance. With due regard to health policies in the 1911 quarantine Ordinance. Jeddah. Passenger status owned by pilgrims is placed as economy class passengers and placed in a low class (laagste klasse). Procedurally the pilgrims deal with hajj agents who legally carry out the organization of people who want to go to Hajj to the Hejaz land. In this provision also stipulated that there were 6 Hajj embarkation ports, among others, Makassar, Surabaya, Tanjung Priok, Emena (Padang), Palembang, and Sabang [19].

Based on the above explanation, Tere Liye concocted the story in his novels with various historical touches that happened in the past. These historical traces can basically be developed into teaching materials, especially Indonesian language learning materials in learning competencies 3.3, $3.4,4.3$, and 4.4 of class XII of high school students, whose material is based on the historical narrative text which has limitations in terms of the choice of historical narrative text. The limitations of this text open up opportunities for Tere Liye's novels to be developed into teaching material. Fragments from the novel if the trophy is reconstructed following the structure of the historical narrative text, it will be able to meet the teaching material requirements following the 2013 curriculum.

\section{CONCLUSION AND SUGGESTIONS}

Based on the results of the analysis and discussion, it can be put forward several things as conclusions. These are historical traces found in the four Tere Liye novels, the history of the Indonesian Communist Party in the novel Tentang Kamu and Anak Cahaya. In these two novels the history of the Indonesian Communist Party is proven by the historical fact that the Communist betrayal did occur in Indonesia in 1948 and 1965. Likewise, in the novel Rose and Sunset, there are historical traces of the Bali bombings. Historical facts prove that there was a big explosion in 2002 in the Kuta area of Bali. The journey Hajj in the Dutch colonial era, contained in the novel Rindu. The takeover of the pilgrimage from Kiyai by the Dutch by providing a steamboat that occurred in the 1900s became a historical fact that supported it. The results of this analysis can be developed as teaching materials, especially for historical story text material in high school.

\section{REFERENCES}

J. Imani, A. I. Al-Ma'ruf, and M. Hum, "Aspek Sosial Novel Amelia Karya Tere Liye dan Relevansinya sebagai Materi Bahan Ajar Bahasa Indonesia di Sekolah Menengah Atas (Kajian Sosiologi Sastra)." Universitas Muhammadiyah Surakarta, 2018.

[2] R. D. Pradopo, Beberapa teori sastra, metode kritik, dan 
penerapannya. Pustaka Pelajar, 1995.

[3] B. Nurgiyantoro, Teori pengkajian fiksi. UGM press, 2018.

[4] M. A. Rokhman, "Sastra Interdisipliner: Menyandingkan Sastra," Yogyakarta: Qalam, 2003.

[5] N. L. Sari, E. Agustina, and B. Lubis, "NILAI-NILAI SOSIAL DALAM NOVEL TENTANG KAMU KARYA TERE LIYE KAJIAN SOSIOLOGI SASTRA," J. Ilm. KORPUS, vol. 3, no. 1, pp. 55-65, 2019.

[6] D. Nuraeni, "STRUKTUR WACANA DALAM NOVEL RINDU KARYA TERE LIYE," DIKSATRASIA, vol. 1, no. 2, pp. 39-51, 2017.

[7] H. Agustyaningrum, P. Purwadi, and E. Suryanto, "Analisis Struktural Dan Nilai Pendidikan Karakter Novel Pukat Karya Tere Liye Serta Relevansinya Terhadap Materi Pembelajaran Bahasa Indonesia Di SMA," BASASTRA, vol. 4, no. 1, pp. 102-119, 2017

[8] E. Wibowo, "Kajian Nilai-Nilai Historisme Dalam Novel Trilogi Soekram Karya Sapardi Djoko Damono," J. Kibas Cenderawasih, vol. 14, no. 2, pp. 207-220, 2017.

[9] G. Widodo and J. Joko, "Pengembangan Dan Implementasi Perangkat Pembelajaran Berbasis Proyek," Innov. Vocat. Technol. Educ., vol. 11, no. 1, 2015.

[10] A. Syahid, "Pengembangan Bahan Ajar Mata Kuliah Rancangan Pembelajaran dengan Menerapkan Model Elaborasi," Univ. Negeri Malang, 2003.

[11] et. al Haeruddin, Pembelajaran Bahasa Indonesia. akarta: Dirjen Pendidikan Tinggi Depdiknas, 2007.

[12] L. J. Moleong, Metode Penelitian Kualitatif (18th Eds. PT Remaja Rosda Karya: PT Remaja Rosda Karya, 2004.

[13] A. Basid, N. I. Jannah, and M. Z. Hamzah, "pOLA keHiDUpAN MAsYArAkAT pONTiANAk DALAM NOVeL kAU, AkU, DAN sepUCUk ANGpAU MerAH kArYA Tere LiYe BerDAsArkAN perspekTiF sTrUkTUrALisMe GeNeTik," Lingua, vol. 14, no. 2, pp. 97-111, 2018.

[14] T. Liye, Tentang Kamu. Jakarta: Republika, 2016.

[15] A. B. Al-Barq, "Pembantaian PKI 1948 di Magetan Jawa Timur," 2017.

[16] T. Liye, Si Anak Cahaya. Jakarta: Republika.

[17] T. Liye, Sunset \& Rosie. Jakaratal: Republika, 20181.

[18] B. Abimanyu, Teror bom di Indonesia. Grafindo Khazanah Ilmu, 2005.

[19] T. Liye, Rindu. Jakarta: Republika. 